4. Паламарчук В.А. Типологія форм самозайнятості. Проблеми підвищення ефективності інфраструктури. 2010. С. 25-29.

5. Почепцов Г. Имидж: от фараонов до президентов. Строительство воображаемых миров в мифе, сказке, анекдоте, рекламе, пропаганде и паблик рилейшенз : монографія. К. : АДЕФ-Украина, 2007. 328 с.

6. Ольшанский Д. В. Политический консалтинг. СПб. : Питер, 2005. $448 \mathrm{c}$.

7. Стефанчук Р.О. Захист честі, гідності та репутаиії 6 иивільному праві. Монографія. К. : Науковий світ. 2001. 307 с.

8. Конвенції про захист прав людини і основоположних свобод : від 04. 11. 1950p. URL: https://zakon.rada.gov.ua/laws/show/995_004.

DOI https://doi.org/10.30525/978-9934-588-92-1-39

\title{
ВПЛИВ ВОСННИХ ДІЙ І ТЕРОРИСТИЧНИХ АКТІВ НА ФУНКЦІОНУВАННЯ МЕХАНІЗМУ ЦИВІЛЬНО-ПРАВОВОЇ ВІДПОВІДАЛЬНОСТІ
}

\author{
Примак В. Д. \\ доктор юридичних наук,
}

професор кафедри міжнародного, цивільного та комериійного права

Киїського національного торговельно-економічного університету

м. Київ, Украӥна

Норми міжнародного права щодо захисту прав жертв злочинів (терористичних актів зокрема) і порушень міжнародного гуманітарного права, а також внутрішньо переміщених осіб значною мірою орієнтовані на визначення належних форм ефективного відшкодування завданої шкоди, серед яких чільне місце посідає питання матеріальної компенсації за майнові та немайнові втрати, що їх зазнають потерпілі особи.

Окреслені проблеми зумовлюють потребу у виявленні у порушеному контексті різноманітних взаємозв'язків положень міжнародного права, 3 одного боку, та норм i принципів інституту цивільно-правової відповідальності - з іншого. Водночас слід констатувати інтегральний, міждисциплінарний характер інституту відшкодування шкоди, завданої жертвам злочинів, терористичних актів, серйозних порушень міжнародного гуманітарного права і прав людини. При цьому сутнісну 
своєрідність позначеному нормативно-правовому утворенню надає притаманна йому взаємодія засад справедливості й солідарності, на які, зокрема, спирається у своїй преамбулі Свропейська конвенція про відшкодування шкоди жертвам насильницьких злочинів від 24.11.1983.

Як такий механізм цивільно-правової відповідальності об'єднує сукупність правових приписів і правових засобів прямої дії, спрямованих на забезпечення взаємопов'язаних груп регулятивних (майнових i особистих немайнових) та охоронних (з відшкодування майнової i моральної шкоди зокрема) відносин через реалізацію притаманних їй превентивної (запобіжної) й компенсаційної функцій. До переліку складових цього багатофункціонального правового комплексу доцільно включити: 1) встановлені законом форми примусового (у судовому порядку або шляхом вчинення виконавчого напису нотаріусом) чи добровільного 3 боку боржника виконання покладеного на нього обов'язку 3 відшкодування завданої кредиторові шкоди; 2) свободу волевиявлення потерпілої сторони щодо застосування відповідних способів захисту суб'єктивних цивільних прав; 3) визначення у законодавстві порушення суб'єктивного цивільного права як підстави цивільної відповідальності та закріплення загального переліку їі умов, що можуть змінюватися залежно від особливостей застосування конкретних санкцій та допустимого розсуду сторін договірних правовідносин (зокрема, 3 виключенням у встановлених законом чи передбачених договором випадках вини зі складу спеціальних умов відповідальності); 4) норми про позовну давність; 5) передбачені у законодавстві види цивільно-правової відповідальності (договірна, позадоговірна; часткова, солідарна, субсидіарна; регресна; повна, обмежена, підвищена за розміром); 6) конкретні санкції (форми, заходи) цивільно-правової відповідальності (відшкодування збитків, стягнення неустойки, процентів річних за прострочення виконання грошового зобов’язання та інфляційних втрат кредитора, втрата завдатку чи сплата його подвійної суми, разова грошова компенсація за порушення прав інтелектуальної власності та компенсація моральної шкоди); 7) закріплення як загального правила у договірній відповідальності, а в окремих випадках також i в нормах деліктного права так званої відповідальності за дії третіх осіб; 8) утвердження принципів повного відшкодування завданої шкоди і вини як відправних засад цивільноправової відповідальності, дія яких може видозмінюватися або обмежуватися у окремих видах охоронних правовідносин; 9) визначеність критеріїв, що впливають на розмір відповідальності зобов’язаної особи; 10) законодавче або договірне закріплення обставин, що спричиняють звільнення від цивільно-правової відповідальності; 164 
11) правові норми, що визначають активи суб'єкта відповідальності (об'єкти належних йому майнових прав), за рахунок яких можуть бути задоволені вимоги потерпілої сторони; 12) нарешті, як своєрідний стрижень правового регулювання окресленої сфери суспільної життєдіяльності постають власне зобов'язальні відносини цивільноправової відповідальності в єдності їх сторін, об’єкта і змісту.

Втім, в умовах воєнних дій і при вчиненні терористичних актів механізм цивільно-правової відповідальності зазнає певних трансформацій, пов'язаних, насамперед, із закріпленням спеціальних підстав, умов і меж іiі застосування, обставин, що зумовлюють звільнення від відповідальності, а також можливим визначенням відмінних від безпосередніх призвідників шкоди суб'єктів обов'язку з іiі відшкодування.

Основні принципи і керівні положення щодо права на правовий захист і відшкодування шкоди для жертв грубих порушень міжнародних норм у сфері прав людини і серйозних порушень міжнародного гуманітарного права (п. 15 розділу IX «Відшкодування завданої шкоди») передбачають «відшкодування шкоди особам, потерпілим від дій або бездіяльності, що можуть бути пов'язані з державою і які являють собою грубі порушення міжнародних норм у сфері прав людини або серйозні порушення міжнародного гуманітарного права» [1]. Іншими словами, держава - порушник норм міжнародного права несе майнову відповідальність за власні протиправні й винні дії.

Натомість у разі вчинення правомірних дій 3 відсічі зовнішній агресії та протидії тероризмові (і за відсутності недобросовісності або непропорційності у діях представників держави) визначення конкретних форм та меж здійснення компенсаційного захисту осіб, потерпілих від воєнних дій, а також жертв терористичних актів $€$ виключною прерогативою національного права.

Проте, наприклад, у системі права України нині немає правових норм прямої дії, які б закріплювали механізм відшкодування шкоди, заподіяної терористичним актом, за рахунок держави. Норми ст. 19 Закону України від 20.03.2003 № 638-IV «Про боротьбу з тероризмом» i ст. 85 Кодексу цивільного захисту України у такого роду правових ситуаціях не можуть бути застосовані у зв'язку з відсутністю згаданих у текстах зазначених статей спеціальних законів.

Очевидно, у спеціальне законодавство про компенсаційний захист потерпілих від воєнних дій, злочинів (терористичних актів зокрема), порушень прав людини і норм міжнародного гуманітарного права має передбачати першочергове покладення на державу обов'язку 3 відшкодування завданої протиправними діями інших суб'єктів 
майнової і моральної шкоди у разі загибелі або тяжкого ушкодження здоров'я потерпілих осіб. Оскільки йдеться не так про цивільноправову відповідальність у іiі власному розумінні, а радше про вияв публічно-правової підтримки й соціальної солідарності, у перспективних законодавчих актах слід закріпити розумні обмеження дії притаманних деліктному праву принципів вини і повного відшкодування шкоди, а також особливості взаємодії матеріально-правових і процесуальних гарантій захисту інтересів потерпілого та держави у правовідносинах з безпосередніми призвідниками шкоди.

Серед іншого, межі такого компенсаційного захисту можуть бути напряму обумовлені фінансовими можливостями держави. 3 іншого боку, очевидною $\epsilon$ необхідність урахування «зустрічної вини» потерпілої особи, якщо поведінка останньої сприяла виникненню шкоди, а так само й поширення правового режиму регресних зобов'язань на відносини між державою, яка виплатила компенсацію, та безпосереднім заподіювачем шкоди.

Натомість регулятивні договірні відносини, за загальним правилом, в умовах збройного конфлікту й вчинення терористичних актів продовжують регулюватися відповідно до принципів належного i реального виконання зобов'язання, а договірні охоронні відносини - на засадах принципу повного відшкодування завданої шкоди (збитків) i принципу вини (з передбаченими законом обмеженнями - зокрема, щодо об'єктивної відповідальності професійного зберігача або іншого суб'єкта підприємницької діяльності).

При цьому збройний конфлікт або терористичний акт у контексті його впливу на формування сукупності умов, необхідних для застосування того чи іншого способу захисту цивільних прав та інтересів, заходу цивільно-правової відповідальності зокрема, здатен (але не обов'язково буде) поставати як обставина, наділена: а) всіма ознаками суб'єктивного випадку; б) окремими властивостями суб'єктивної або об'єктивної непередбачуваності чи невідворотності; в) цілісним комплексом характеристик непереборної сили. Зазначені характеристики впливу збройного конфлікту або терористичного акта набувають того чи іншого правового значення винятково у разі доведення заінтересованою стороною факту їх наявності саме на момент порушення зобов'язання. Зокрема, професійний зберігач у відповідному випадку має довести належними i допустимими доказами, що неповернення ним належного поклажодавцеві майна сталося внаслідок непереборної сили.

Разом з тим дещо ширше юридичні факти, виникнення або наслідки яких значною мірою обумовлені збройним конфліктом, у розрізі 166 
застосування належних способів цивільно-правового захисту загалом можуть бути кваліфіковані або як причина порушення суб'єктивних прав та інтересів особи (спосіб заподіяння шкоди зокрема), або як обставини, що звільняють заінтересовану особу від відповідальності (непереборна сила, випадок, самозахист тощо), або як підстава для припинення правовідносин через неможливість реалізації їх змісту, або як істотна зміна обставин, що має бути взята до уваги 3 метою додержання засад справедливості, розумності й добросовісності при визначення правового становища сторін певних правовідносин.

\title{
Література:
}

1. Основні принципи і керівні положення щодо права на правовий захист i відшкодування шкоди для жертв грубих порушень міжнародних норм у сфері прав людини і серйозних порушень міжнародного гуманітарного права (схвалені Комісією з прав людини $\mathrm{OOH}$ 25.07.2005). URL: http://zakon3.rada.gov.ua/laws/show/995_e53 (дата звернення: 27.10.2020).

DOI https://doi.org/10.30525/978-9934-588-92-1-40

\section{ПРОТИПРАВНІСТЬ ЯК ОБ'СКТИВНА УМОВА ВИНИКНЕННЯ ЦИВІЛЬНО-ПРАВОВОЇ ВІДПОВІДАЛЬНОСТІ ЗА ПОРУШЕННЯ АВТОРСЬКОГО ПРАВА}

\author{
Ромась Д. С. \\ аспірант кафедри циивільного права та прочесу \\ Хмельницького університету управління та права \\ імені Леоніда Юзькова \\ м. Хмельницький, Украӥна
}

Підставою виникнення цивільно-правової відповідальності $\epsilon$ цивільне правопорушення, для якого характерна сукупність об'єктивних та суб'єктивних умов для покладення відповідальності на порушника. Так, С.Д. Гринько об'єктивні умови пов'язує з діяльністю людини у зовнішньому світі, а суб'єктивну умову характеризує як вольовий і свідомий людський фактор, який зумовив діяльність людини у зовнішньому світі [1, с. 224]. 